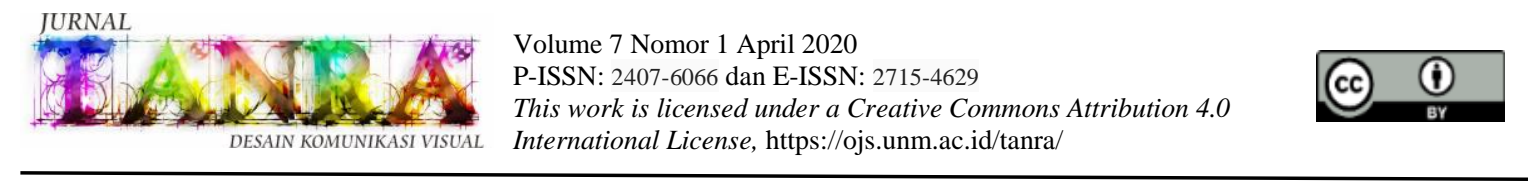

\title{
PENGENALAN CERITA RAKYAT “ASSALENNA CAKKELLEQ RIALA LAMBANG RI SOPPENG"
}

\author{
Nurhikma Rustang \\ Desain Komunikasi Visual, Fakultas Seni dan Desain, Universitas Negeri Makassar \\ nurhikmar3@gmail.com
}

\begin{abstract}
ABSTRAK
Perancangan ini bertujuan membuat anak-anak memahami sejarah Kabupaten Soppeng khususnya cerita tentang Assalenna Cakkelleq riala lambang ri Soppeng sejak dini hingga mereka besar nanti serta menjadi referensi bagi anak-anak dan dapat membuat anak-anak tertarik mempelajari bahasa daerah. Metode yang digunakan dalam perancangan ini adalah metode Research and Development (Penelitian dan Pengembangan). Metode pengembangan yang akan digunakan yaitu model pengembangan 4-D (Four-D Model). Tahapan yang dimaksud yaitu Define, Design, Develop, dan Disseminate. Namun, tahap-ahap yang dilakukan hanya 2 yaitu tahap Define dan Design. Data-data penelitian diperoleh dari data pustaka, data dari beberapa narasumber yaitu (1) Penulis cerita, H. Sukarding K., S.Pd., M.Si., (2) Guru SMP, Marlina, S.Pd., (3) Guru MTs DDI Walimpong, Jukriani, S.Pd., dan data dari angket tentang cerita rakyat yang dibagikan kepada siswa-siswi SD dan SMP. Konsep desain dalam cerita rakyat Assalenna Cakkelleq Riala Lambang ri Soppeng yaitu tentang petualangan orang zaman dahulu mencari pemimpin untuk Kabupaten Soppeng yang sedang dilanda kekacauan. Hasil perancangan ini terdiri dari (1) Media utama berupa Komik Assalenna Cakkelleq Riala Lambang ri Soppeng, (2) Media pendukung dalam bentuk merchandise berupa (a) Totebag, (b) T-shirt, (c) X-banner, (d) Stiker, (e) Gantungan Kunci.
\end{abstract}

Kata kunci: Sejarah; lambang Soppeng; komik; cerita rakyat

\section{ABSTRACT}

This design aims to make the children understand the history of Soppeng Regency especially the story of Assalenna Cakkelleq ri Soppeng trophy symbol from an early age until they grow up and become a reference for children and can make children interested in learning regional languages. The method used in this design is the Research and Development method. The development method that will be used is the 4-D development model (Four-D Model). The stages in question are Define, Design, Develop, and Disseminate. However, there were only two stages, namely the Define and Design stages. Research data obtained from library data, data from several sources, namely (1) Story writer, H. Sukarding K., S.Pd.m M.Si., (2) Middle School Teacher, Marlina, S.Pd., (3) Teacher MTs DDI Walimpong, Jukriani, S.Pd., and data from a questionnaire about folklore that was distributed to elementary and junior high school students. The design concept in Assalenna Cakkelleq Riala Lambang ri Soppeng folklore is about the adventures of the ancients looking for a leader for Soppeng District which is being hit by chaos.The results of this design consisted of (1) The main media in the form of Comics Assalenna Cakkelleq Riala Lambang ri Soppeng, (2) Supporting media in the form of merchandise in the form of (a) Totebag, (b) T-shirt, (c) X-banner, (d) Stickers, (e) Key Chains.

Keywords: History of the Soppeng symbol, comics, Soppeng folklore

\section{PENDAHULUAN}

Cerita rakyat merupakan kesusastraan dari masyarakat 'primitif' yang belum mengenal tulisan (Murti Bunanta, 1998:22). Sebagai masyarakat yang belum mengenal tulisan, ekspresi secara lisan merupakan satusatunya sarana yang paling efektif untuk 
berkomunikasi. Oleh karenanya, cerita dan berbagai bentuk yang kini dikenal kesastraan pun diekspresikan secara lisan, misalnya dengan cara diceritakan atau dinyanyikan secara keras dihadapan sekelompok masyarakat pada waktu-waktu tertentu yang dilakukan oleh tukang cerita.

Keberadaan cerita rakyat ini diwariskan secara turun-temurun dan umumnya tidak diketahui pengarangnya karena kemunculannya pun tidak sengaja dan berlangsung dari waktu ke waktu, dan tidak sekaligus seperti halnya penulisan sastra dewasa ini. Jadi, ia milik masyarakat. (Anafiah, 2015: 128).

Masyarakat kota tidak terlalu mengerti tentang adat - istiadat karena adat istiadat tersebut warisan dari orang- orang yang lebih tua dari pada kita. Di perkotaan kebanyakan para pendatang sehingga jarang yang membawa kebudayaan setempat, banyaknya para pendatang juga mengakibatkan perbedaan budaya sehingga mereka mengaggap kebudayaa tidak terlalu penting. Sedangkan di masyarakat desa adat - istiadat sangat di hidupkan karena beranggapan adat - istiadat itu warisan para leluhur yang sudah turun temurun, mereka masi sangat percaya dengan kebudayaan dan masih menjalankan dengan baik. Adat - istiadat jika tidak dilakukan di masyarakat desa mereka berfikir hal yang tidak - tidak (Erine, 2017)

Oleh karena itu mata pelajaran mengenai sejarah atau asal-usul kota Soppeng dimuat dalam sebuah cerita rakyat pada buku Bahasa Daerah atau Muatan Lokal. Dalam buku tersebut di paparkan beberapa paragraf yang membahas tentang Assalenna Cakkelleq riala lambang ri Soppeng (Asal-usul Kaka Tua menjadi lambang Soppeng) yang di dalamnya ada beberapa tokoh, hewan berupa burung kakatua, dan lain-lain. Pelajaran tersebut dipelajari pada bangku SMP kelas VIII, namun tidak semua pelajar SMP memperoleh materi tentang Asal Mula Burung Kakatua dijadikan Lambang Soppeng (Siswa kelas VIII di MTs DDI Walimpong) walaupun sebenarnya sudah terdapat buku yang memuat tentang hal tersebut. Buku yang di maksud adalah Buku Bahasa Daerah kelas VIII yang berjudul Ada Madeceng. Sedangkan di bangku SD memang belum mendapat pelajaran tentang Sejarah Soppeng atau semacamnya berdasarkan observasi yang telah dilakukan pada bulan Desember 2018 di MI DDI Coppeng-coppeng dan MTs DDI Walimpong di Kabupaten Soppeng.

Berdasarkan observasi, sebagian besar Anak usia SD dan SMP tertarik pada gambargambar (ilustrasi) dan warna. Dalam hal ini dibutuhkan hal yang menarik dengan menampilkan ilustrasi yang mengandung unsur estetika yang tinggi dan juga bahasa yang mudah dimengerti sehingga dapat meningkatkan minat baca anak-anak. Namun pada kenyataannya, setelah melakukan observasi, buku Bahasa Daerah tersebut hanya memaparkan tulisan dan gambar yang sangat sedikit dan tidak berwarna. Hal tersebut kurang menarik minat baca anak.

Masyarakat Soppeng, terutama anak SD yang menganggap kelelawar adalah lambang Kabupaten Soppeng. Dalam observasi yang dilakukan, hanya $10 \%$ yang pernah mendengar cerita tentang "Assalenna Cakkelleq Riala Lambang ri Soppeng”, 90\% mengaku tidak mengetahui cerita tersebut.

Berdasarkan survei, 14 dari 21 anak Madrasah Ibtidaiyah Darud Da'wah wal Irsyad Coppeng-coppeng (SD) mengatakan yang menjadi lambang Kabupaten Soppeng itu adalah Kelelawar, sedangkan 2 dari 21 anak mengatakan Kuda, dan hanya 5 anak yang mengatakan Kakatua. Hal tersebut menjadi sebuah kesenjangan karena lambang sesungguhnya dari Kabupaten Soppeng adalah burung kakatua bukanlah Kelelawar ataupun kuda.

Lambang Daerah Kabupaten Soppeng terdiri dari 3 (tiga) bagian yang menggambarkan unsur-unsur sejarah, kebudayaan dan ekonomi yang keseluruhannya merupakan bagian mutlak yang tidak terpisahkan dari Negara Kesatuan Republik Indonesia yaitu Burung Kakatua, memegang padi, jagung daun tembbakau dan daun kapas (https://soppengkab.go.id/artilambang/).

Masalah yang menjadi kesenjangan lainnya yaitu salah satu guru MTs DDI Walimpong mengabisa takan bahwa sejak diberlakukannya Kurikulum 2013, siswa sudah tidak mendapat pelajaran Bahasa Daerah karena telah dihilangkan dari kurikulum.

Adapun tujuan dari perancangan ini yaitu membuat anak-anak tertarik mempelajari 
bahasa daerah serta anak juga dapat memahami cerita tentang Sejarah Kabupaten Soppeng itu sendiri, terutama Cerita Rakyat tentang Assalenna Cakkelleq riala Lambang ri Soppeng. Pembelajaran di usia dini diharapkan menjadi efektif bagi kehidupan anak-anak ke depannya terutama untuk mengetahui sejarah tanah kelahirannya sendiri. Sehingga pada saat pertanyaan muncul, anak-anak bisa menceritakan dengan caranya sendiri, tidak dengan hanya menghapal kalimat atau paragraf tetapi betul- betul memahami hal tersebut melalui rancangan visualisasi.

Melalui cerita-cerita yang baik, sesungguhnya anak-anak tidak hanya memperoleh kesenangan atau hiburan saja, tetapi mendapatkan pendidikan yang jauh lebih luas. Bahkan tidak berlebihan bila dikatakan bahwa cerita ternyata menyentuh berbagai aspek pembentukan kepribadian anak anak. Cerita secara faktual erat sekali hubungannya

Dengan pembentukkan karakter, bukan saja karakter manusia secara individual, tetapi juga karakter manusia dalam sebuah bangsa (Anafiah,2017).

Ilustrasi memiliki peran dalam membangun kesadaran intelektual, kesadaran teknologi, kesadaran politis, kesadaran edukatif, kesadaran akan perkembangan budaya serta peradaban manusia dari masa prasejarah hingga masa kini (Maharsi, 2016)

Ada beberapa tinjauan desain yang relevan dengan perancangan ini, yaitu:

\section{Pengembangan Komik Digital Berbasis Nilai Karakter Sebagai Media Pembelajaran Akuntansi Pada Kompetensi Dasar Akuntansi Persediaan Di Kelas Xi Akuntansi SMK Negeri 2 Purworejo Tahun Ajaran 2015/2016.}

Berdasarkan hasil wawancara dan observasi dengan guru akuntansi SMK Negeri 2 Purworejo menjelaskan bahwa waktu yang tersedia di semester dua sangat singkat untuk kelas XI dalam menerima pelajaran dikarenakan banyaknya waktu yang digunakan untuk persiapan dan latihan serangkaian ujian nasional. Cara penyampaian awal dalam materi akuntansi persediaan yang menjelaskan teoriteori akuntansi persediaan dengan membaca buku yang sudah di sediakan oleh sekolah dan buku yang sudah dimiliki masing-masing siswa serta menggunakan metode ceramah. Situasi ini dinilai kurang menarik minat siswa untuk mempelajari materi tersebut. Disisi lain penggunaan media pembelajaran dalam pelajaran akuntansi sudah dilakukan, namun dalam praktiknya masih belum optimal, peserta didik masih terfokus kepada guru. Hal ini karena guru dalam penyampaian materi akuntansi kurang memanfaatkan teknologi yang ada sebagai media pembelajaran.

Kesimpulan dari perancangan ini adalah penelitian pengembangan media pembelajaran komik digital berbasis nilai karakter dikembangkan dengan menggunakan 4 tahap yang menunjukkan hasil sebagai berikut: a) Define, Tahap define menghasilkan produk yang sesuai untuk dikembangkan sebagai media pembelajaran dalam standar kompetensi akuntansi persediaan yaitu komik digital berbasis nilai karakter. 2) Design, Tahap design terdiri atas tiga hasil, diantaranya a) tes acuan patokan dengan menggunakan angket, $b$ ) pemilihan media menggunakan komik digital berbasis nilai karakter, c) pemilihan format menggunakan software adobe flash CS6, d) rancangan awal terdiri dari finishing produk sebelum validasi ahli. 3) Develop, Tahap develop menghasilkan komik digital berbasis nilai karakter yang divalidasi oleh ahli, guru akuntansi dan siswa kelas XI Akuntansi 1 dan 2 SMK Negeri 2 Purworejo. Ahli Materi diperoleh rata-rata 4,15 kategori layak, Ahli Media diperoleh rata-rata 4,81 kategori sangat layak, Guru Akuntansi SMK diperoleh ratarata 4,82 kategori sangat layak, Siswa kelas XI Akuntansi 1 dan 2 diperoleh rata-rata 0,90 dan 0,93 kategori sangat layak, Angket nilai karakter sebelum pengembangan dan sesudah pengembangan diperoleh rata- rata peningkatan pada nilai karakter jujur meningkat 19\%; disiplin meningkat 4\%; mandiri meningkat $10 \%$; kreatif meningkat 26\%; kerja keras meningkat 4\%. Pada uji validasi, aspek nilai karakter jujur meningkat $15 \%$; disiplin meningkat $8 \%$; mandiri meningkat $12 \%$; kreatif meningkat $18 \%$; kerja keras meningkat 17\%.4) Disseminate, Tahap disseminate, menghasilkan penyebaran produk komik digital berbasis nilai karakter di kelas XI Akuntansi 1, 2, 3, dan 4 SMK Negeri 2 Purworejo (Sambada, 2016). 


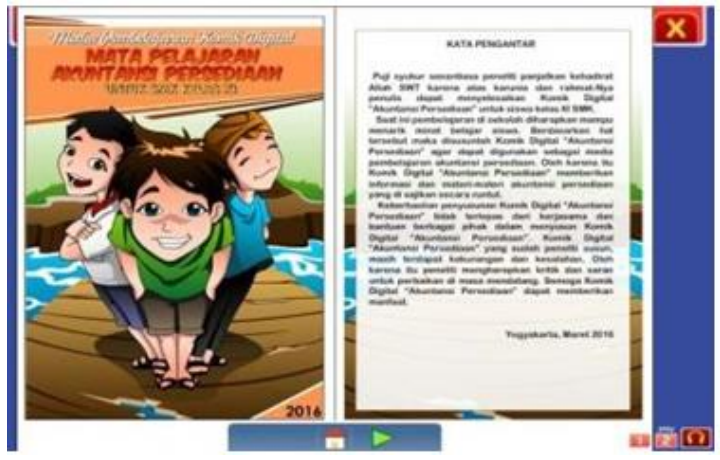

Gambar 1. Hasil perancangan komik digital (Sambada, 2016).

\section{Perancangan Komunikasi Visual Komik Berbasis Cerita Rakyat Timun Mas}

Cerita dan pesan moral pada cerita rakyat Timun Mas ini layak untuk disampaikan ke generasi muda karena dalam cerita rakyat tersebut tersebut mencerminkan budaya suatu bangsa, dan menjadikan cerita rakyat merupakan identitas bangsa tersebut, karena itu untuk menarik perhatian generasi muda terhadap cerita rakyat tersebut maka media komik yang merupakan media populer yang berkembang saat ini merupakan pilihan yang tepat. Komposisi antara gambar dan teks menjadikan komik mudah dimengerti dan menarik bagi generasi muda.

Namun ketatnya persaingan dan dominasi komik Import menjadikan cerita rakyat yang ingin diangkat dalam media komik juga dapat dikembangkan sehingga dapat bersaing dengan komik-komik Impor tanpa melupakan nilai moral yang ada pada cerita asalnya. Dimana nantinya dengan mengembangkan komik yang berangkat dari cerita rakyat dapat menjadi identitas pembeda antara komik Indonesia dan komik impor, pengembangan cerita juga diharapkan dapat menjadikan komik lokal Indonesia dapat bersaing dalam industri komik secara luas baik itu dalam lingkup nasional maupun internasional, dan dengan mengangkat cerita yang berangkat dari cerita rakyat pada nantinya dapat berdampak pada meningkatnya aware terhadap karakter-karakter dan budaya lokal Indonesia, selain itu pesan moral yang ada pada cerita rakyat juga dapat menjadi teladan bagi sikap dan kepribadian generasi muda. Berikut adalah hasil perancangan yang ada pada komik Cucumber Conquest, mulai dari karakter, sampai pada hasil akhir komik (Lesmana, 2015)

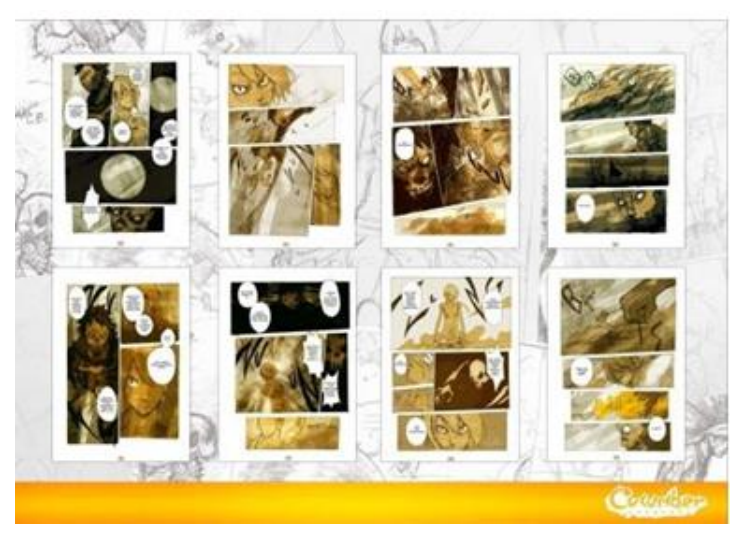

Gambar 1. 2. Hasil perancangan Komik Timun Mas (Lesmana, 2015)

\section{METODE}

Metode yang digunakan adalah Metode Research and Development. Metode pengembangan yang akan digunakan model pengembangan 4-D (Four-D Model), namun tahap yang digunakan adalah tahap define dan design. (Sugiyono; 2015: 407)

a. Define. Tahap define menghasilkan informasi serta media pembelajaran yaitu komik berbasis buku fisik.

b. Design. Tahap design terdiri dari 1) tes acuan atau patokan dengan menggunakan angket, 2) pemilihan, media menggunakan komik berbasis buku fisik, 3) pemilihan format menggunakan software PaintoolSai dan CorelDraw, 4) rancangan finishing produk.

\section{Teknik Pengumpulan Data}

Pada tahap ini dilakukan studi kepustakaan terhadap berbagai referensi berdasarkan kata kunci perancangan, yaitu cerita rakyat, legenda, cerita rakyat lokal, cerita rakyat soppeng, artikel kearifan lokal, serta teori lain yang mendukung.

Wawancara yang dilakukan adalah wawancara mengenai naskah serta sejarah tentang cerita rakyat "Assalenna Cakkelleq Riala Lambang ri Soppeng" pada sejumlah tokoh masayarakat dan dinas pemerintah terkait seperti pemerintah kota Kab. Sopeng, 
bidang kebudayaan, serta wawancara mengenai buku pelajaran bahasa daerah di beberapa sekolah.

Angket/Daftar Pertanyaan Pada tahap ini, penulis membagikan daftar pertanyaan untuk siswa SD dan SMP pada salah satu sekolah di Kabupaten Soppeng. Siswa sekolah dasar yang menjawab kuesioner adalah siswa dari Madrasah Ibtidaiyyah DDI Coppeng-coppeng dan siswa SMP yang menjawab yaitu siswa kelas VIII Madrasah Tsanawiyah Walimpong.

Observasi yang dilakukan adalah dengan mengunjungi tempat-tempat bersejarah yang ada dalam naskah cerita rakyat untuk meneliti dan mendokumentasikan secara langsung.

Teknik Analisis Data yang digunakan dalam menganalisis data yaitu: Teknik copywriter yaitu suatu teknik yang mengatur penggunaan kata sehingga mudah untuk dipahami. Teknik ini digunakan untuk memilih bahasa apa yang digunakan dalam pembuatan media. Analisa objek/materi komunikasi pesan dilakukan pada beberapa poin yaitu naskah cerita rakyat, sinopsis, scene pembabakan, storyline dan storyboard.

Segmentasi yaitu teknik pengelompokan konsumen/target audiens kedalam kelompok dengan ciri-ciri yang sama. Segmentasi ini terbagi menjadi 4 kategori yaitu: secara geografis, demografis, psikografis, dan behaviouristis.

1. Geografis

a. Negara: Indonesia

b. Wilayah: Sulawesi Selatan

c. Kota/Kabupaten: Soppeng

d. Ukuran: Bertempat di desadesa.

2. Demografis

a. Jenis kelamin: Laki-laki dan perempuan

b. Usia: Anak-anak (7-12)

c. Agama: Islam, Kristen,

Hindu, Buddha.

d. Ekonomi: Menengah ke atas

e. Pendidikan: Sekolah Dasar

3. Psikografis

a. Gaya hidup:

1) Anak-anak yang menyukai buku bergambar.

2) Anak-anak yang menyukai cerita/dongeng.
3) Anak-anak yang menyukai tampilan visual seperti cartoon.

b. Kepribadian: Aktif, memiliki imajinasi tinggi dan rasa selalu ingin tahu.

\section{Behaviour}

Masyarakat yang tinggal di kota - kota besar umumnya mempunyai gaya hidup yang glamour atau sering di sebut dengan pola serba mewah, Orang - orang kota cenderung memikirkan diri sendiri tanpa memikirkan orang lain. Fasilitas umum lebih banyak memadai di kota, Adat istiadat kurang dijunjung tinggi oleh masyarakat perkotaan, Pola pikir masyarakat perkotaan umumnya rasional (tidak begitu percaya dengan takhayul), Lapangan pekerjaan juga lebih banyak tersedia untuk orang - orang yang tinggal di kota.

Teknik tabulasi yaitu teknik yang digunakan untuk mendeskripsikan keunggulan dan kekurangan produk yang dihasilkan oleh kompetitor.

Konsep desain dalam cerita rakyat Assalenna Cakkelleq Riala Lambang ri Soppeng yaitu tentang petualangan orang zaman dahulu mencari pemimpin untuk Kabupaten Soppeng yang sedang dilanda kekacauan. Adapun Positioning dan diferensiasi yang digunakan dalam Pengenalan cerita rakyat Assalenna Cakkelleq riala Lambang ri Soppeng (Asal Mula Kakatua dijadikan Lambang Soppeng) yaitu menggunakan visualisasi yang sederhana yang sesuai dengan target audiens, sehingga target audiens dapat lebih mudah mengimajinasikan cerita tersebut. Dan juga akan dirancang berbeda dari kompetitor lain, yaitu menggunakan visualisasi yang menonjolkan wajah/visual yang lokal serta menggunakan gaya visual semicarton/cartoon berdasarkan target audiens yaitu anak-usia 7-12 tahun. Kemudian, media yang akan digunakan yaitu berupa buku ilustrasi atau komik yang diharapkan dapat menghidupkan budaya membaca sejak dini. Dalam hal ini, penggunaan media digital tidak dianjurkan karena selain berpengaruh pada kesehatan mata anak, juga akan berpengaruh pada perkembangan otak dan akan membuat anak menjadi lupa waktu jika terlalu sering bermain gadget. 


\section{HASIL DAN PEMBAHASAN Sumber Inspirasi}

Sumber inspirasi didapat dari observasi langsung, dan browsing internet mengenai tempat-tempat dan karakter.
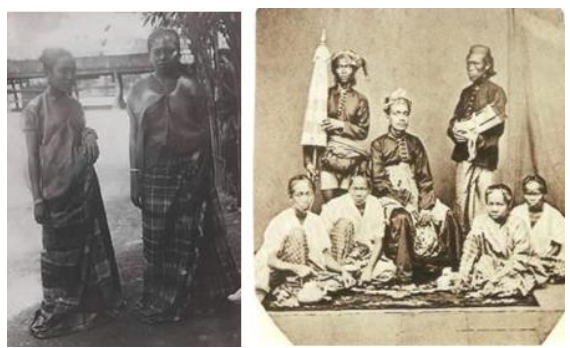

Gambar 3. 1. Pakaian masyarakat bugis Soppeng zaman dahulu (Sumber: Google)

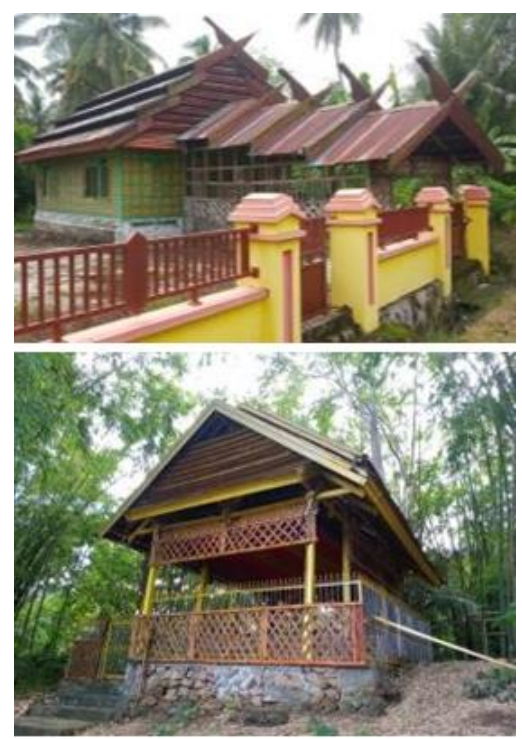

Gambar 3. 2. Rumah tempat ditemukannya Tomanurung (Sumber: Olahan Penulis)

\section{Warna}

Kategori warna yang digunakan dalam perancangan media Pengenalan Cerita Rakyat Assalenna Cakkelleq Riala Lambang ri Soppeng, ada 2 warna yang akan dijadikan warna-warna dominan dalam proses desain yaitu warna hijau dan kuning. Warna hijau dan kuning merupakan warna khas Kabupaten Soppeng yang merupakan warna khusus dan sakral bagi orang-orang bangsawan. Serta penggunaan warna dingin dan panas sebagai warna dasar dalam perancangan.

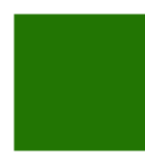

C: $84 \%$ M: $29 \%$ Y: $100 \% \mathrm{~K}: 19 \%$ R: 34 G: 117 B:2 \#227502

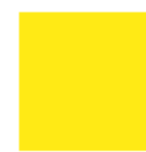

C: $3 \% \mathrm{M}: 2 \% \mathrm{Y}: 96 \% \mathrm{~K}: 0 \%$ R: 225 G: 234 B:22 \#ffea16

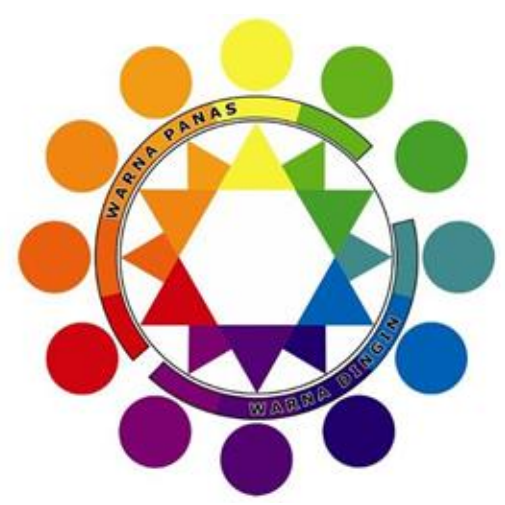

Gambar 3. 3. Warna panas dan warna dingin (Said, A. A. (2006).)

\section{Tipografi}

Tipografi yang akan digunakan dalam perancangan ini yaitu font jenis display. Dengan mempertimbangakan genre cerita rakyat Assalenna Cakkelleq Riala Lambang ri Soppeng yaitu genre adventure serta mempertimbangkan target audiens yaitu anakanak maka adapun jenis tipografi display yang digunakan yaitu font Happy School untuk isi dan untuk judul digunakan font Radiant yang dikombinasikan dengan font Cute Stitch, yaitu sebagai berikut:

Happy School
ABCDEFGHIJKLMNOPQRSTUVWXYZ
abcdefghijklmnopqrstuvwxyz
01234567890
Adventure Script
ABCDEFGHIJKMNOPQRST UVWXYZ
abcdefghijklmnopqrstuvwXyz
1234567890
CUTE STITCH
ABCDEFGHIJLMNOPQRSTU VWXYZ
1234567890




\section{Sketsa}

Berikut adalah sketsa karakter dan suasana yang akan diterapkan dalam komik "Assalenna Cakkelleq Riala Lambang ri Soppeng".
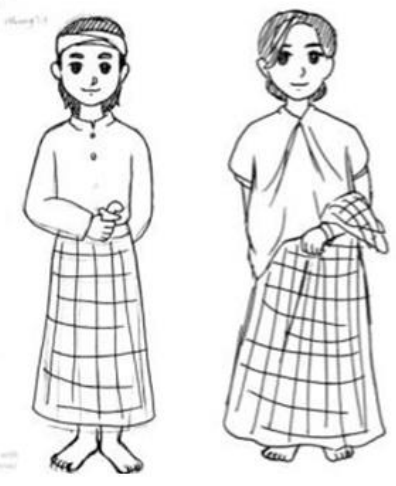

Gambar 3. 4. La Temmamala dan We Temmapuppu (Sumber: Olahan Penulis)
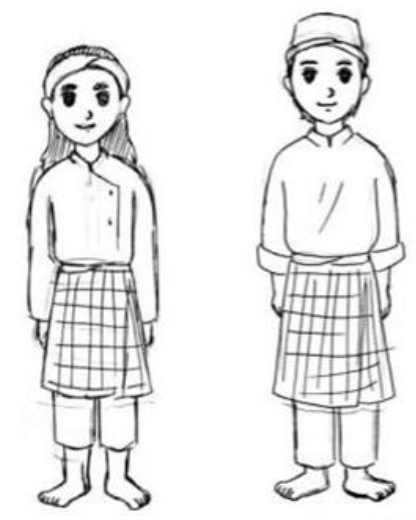

Gambar 3. 5. Matoa Bila dan Matoa Botto (Sumber: Olahan Penulis)

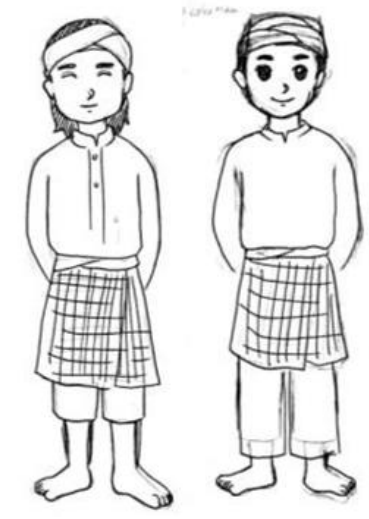

Gambar 3. 6. Matoa Ujung dan Matoa Jumet (Sumber: Olahan Penulis)

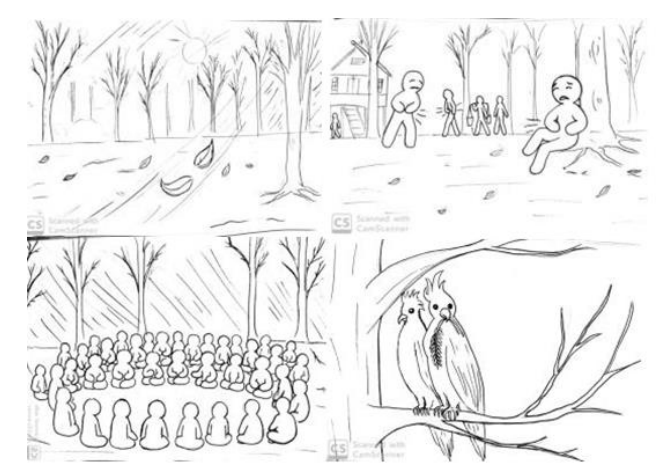

Gambar 3. 7. Sketsa isi komik (Sumber: Olahan Penulis)

\section{Implementasi Digital}

Tahapan implementasi digital melalui 3 tahap yaitu line art, pewarnaan, dan pemberian teks.

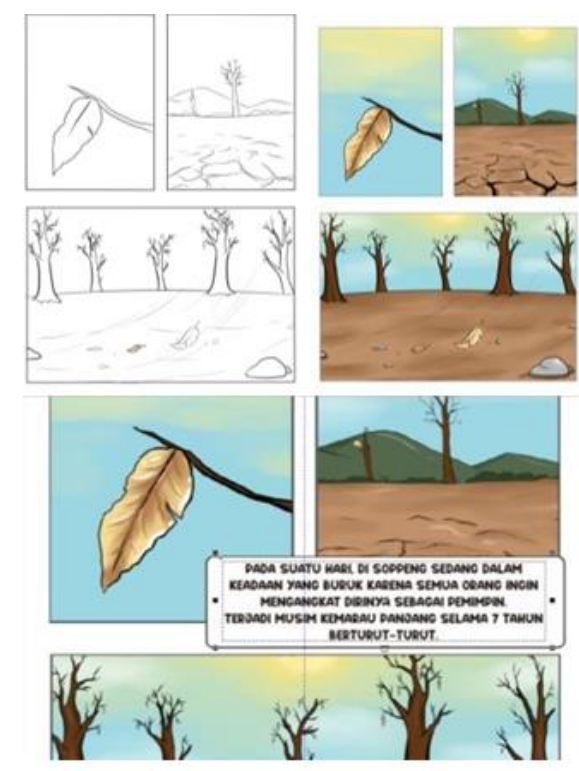

Gambar 3. 8. Proses lineart, pewarnaan, dan penambahan teks (Sumber: Olahan Penulis)

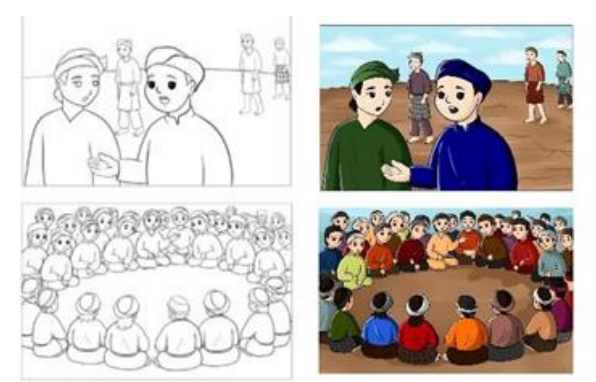

Gambar 3. 9. Proses lineart, pewarnaan, dan penambahan teks (Sumber: Olahan Penulis) 


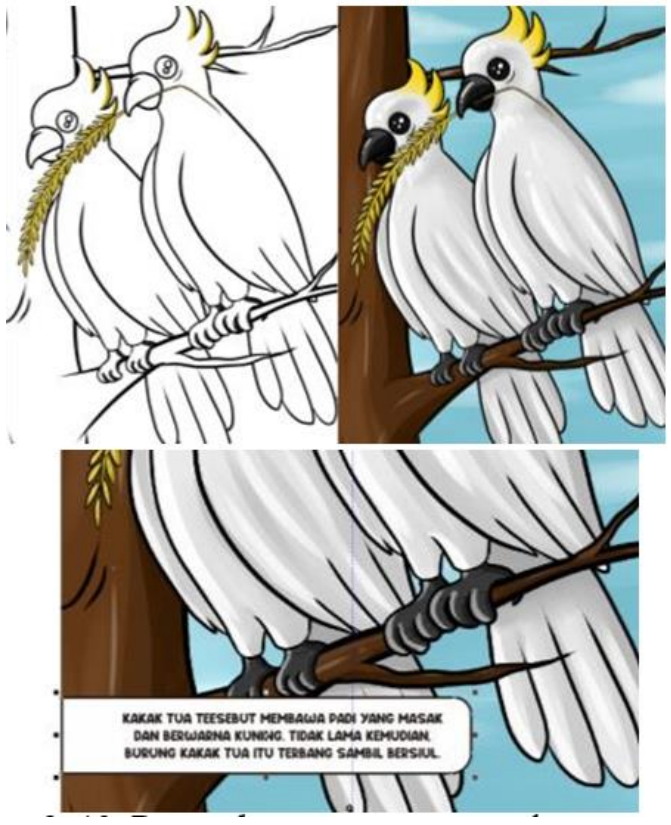

Gambar 3. 10. Proses lineart, pewarnaan, dan penambahan teks (Sumber: Olahan Penulis)

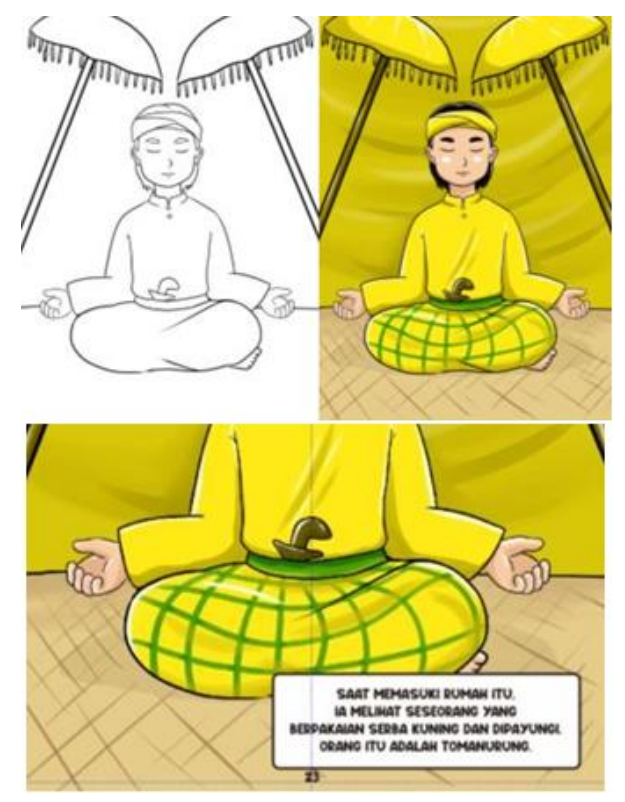

Gambar 3. 11. Proses lineart, pewarnaan, dan penambahan teks (Sumber: Olahan Penulis)

\section{Hasil Perancangan}

Hasil dari perancangan ini adalah media utama Komik "Assalenna Cakkelleq Riala Lambang ri Soppeng" dalam bentuk buku fisik dan media pendukung dalam bentuk merchandise berupa (a) Totebag, (b) T-shirt, (c) X-banner, (d) Stiker, (e) Gantungan Kunci.

\section{Media Utama}

Berikut adalah tampilan final desain cover dan isi komik cerita rakyat Assalenna Cakkelleq Riala Lambang ri Soppeng. Yang ditonjolkan dalam desain ini yaitu burung Kakatua.

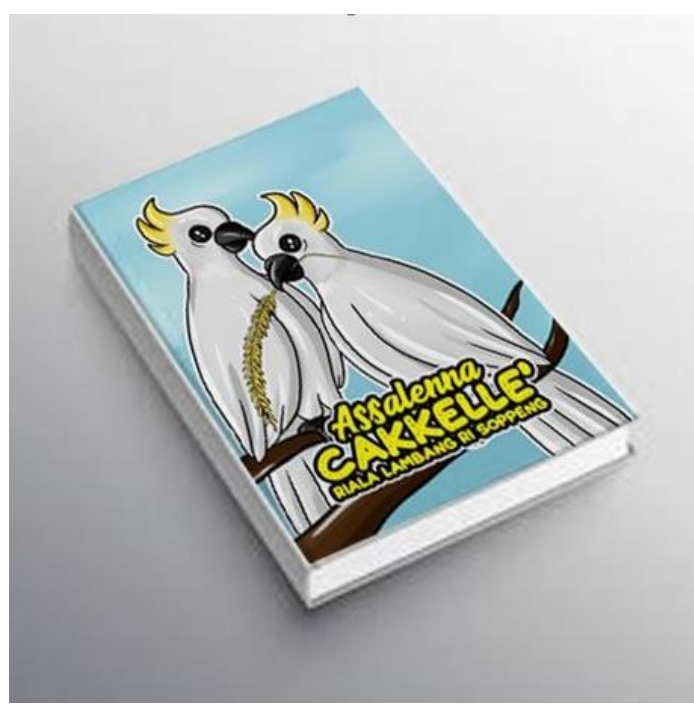

Gambar 3. 12. Tampilan cover komik (Sumber: Olahan

Penulis)
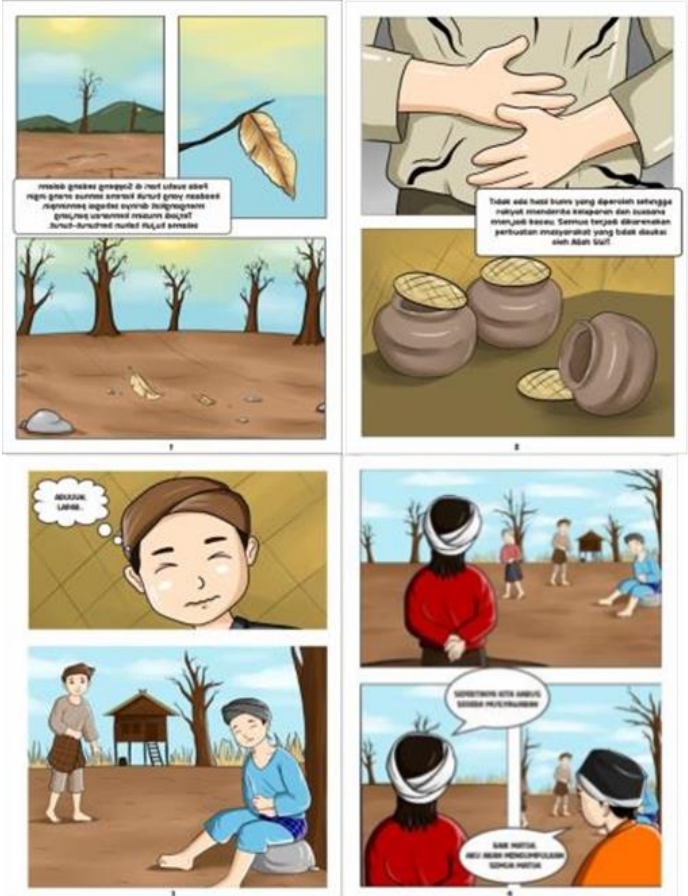

Gambar 3. 13. Halaman 1-4 (Sumber: Olahan Penulis) 


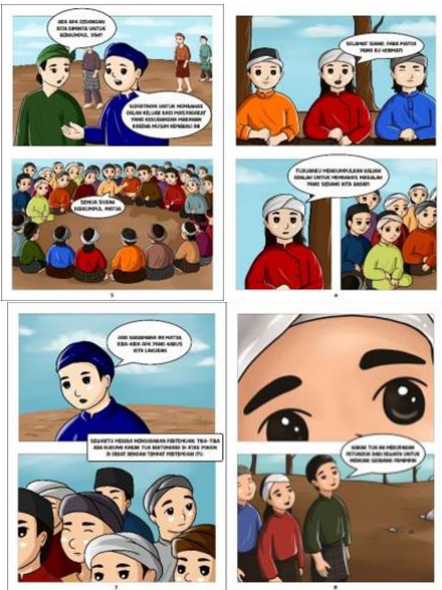

Gambar 3. 14. Halaman 5-8 (Sumber: Olahan Penulis)

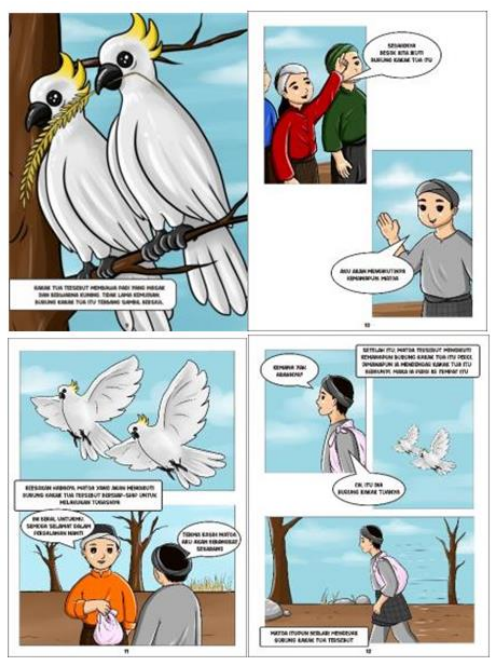

Gambar 3. 15. Halaman 9-12 (Sumber: Olahan Penulis)

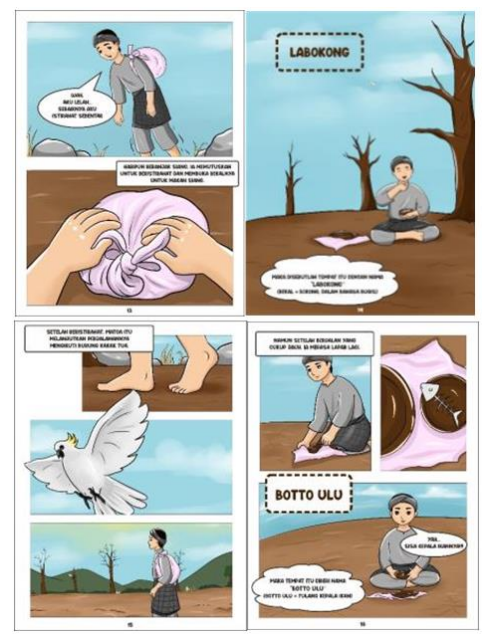

Gambar 3. 16. Halaman 13-16 (Sumber: Olahan Penulis)

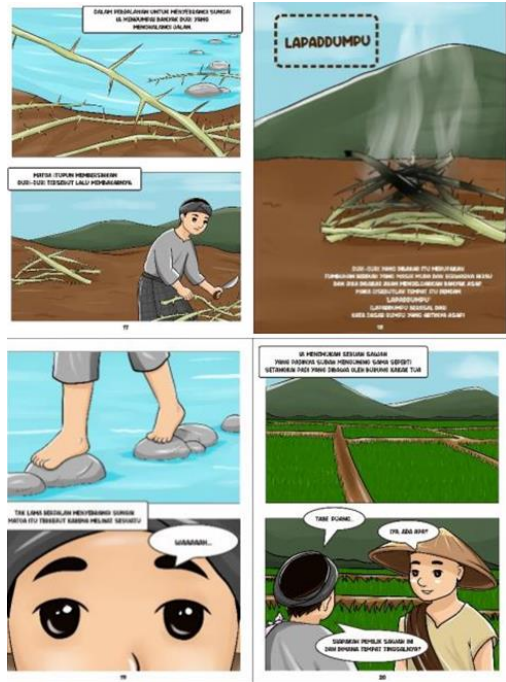

Gambar 3. 17. Halaman 17-20 (Sumber: Olahan Penulis)

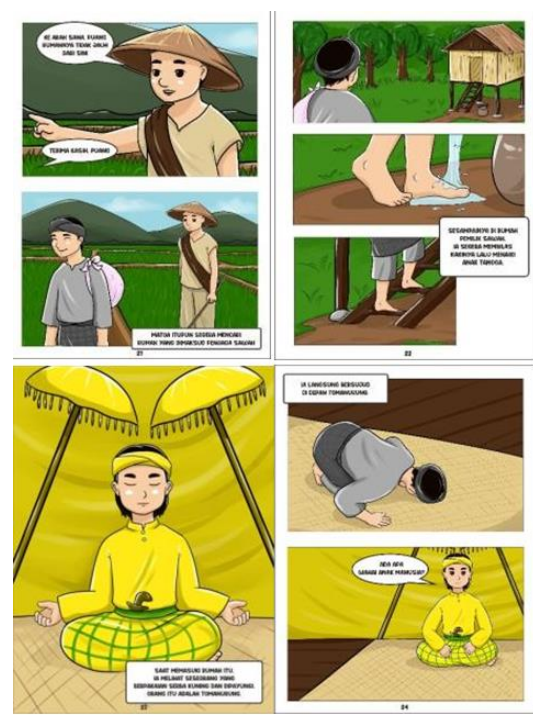

Gambar 3. 18. Halaman 21-24 (Sumber Olahan Penulis)

b) Media Pendukung

Media pendukug yang dibuat dalam perancangan ini berupa merchandise, sebagai berikut:
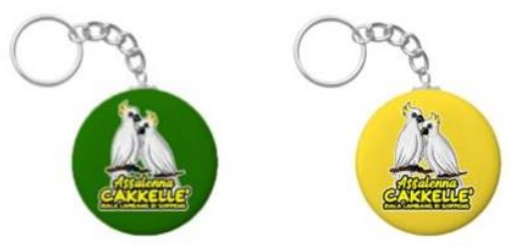

Gambar 3. 19. Gantungan Kunci (Sumber: Olahan Penulis) 


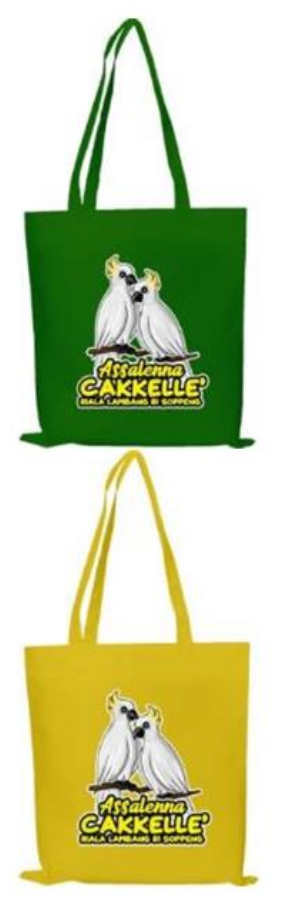

Gambar 3. 20. Tote Bag (Sumber: Olahan Penulis)

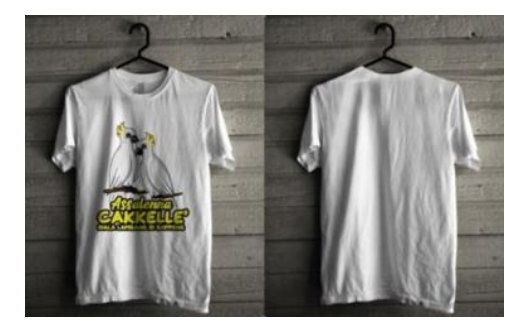

Gambar 3. 21. T-shirt (Sumber : Olahan Penulis)
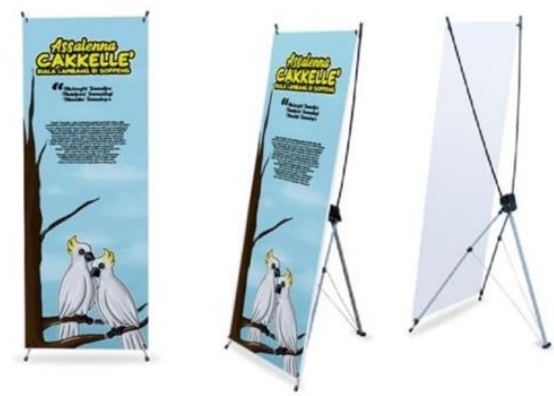

Gambar 3. 22. X-banner (Sumber: Olahan Penulis)

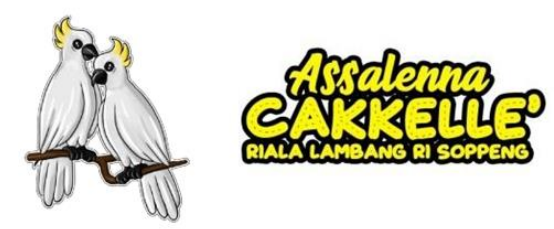

Gambar 3. 23. Stiker (Sumber: Olahan Penulis)

\section{KESIMPULAN DAN SARAN Kesimpulan}

Proses pembuatan komik cerita rakyat Assalenna Cakkelleq Riala Lambang ri Soppeng ini diawali dengan melakukan wawancara dengan penulis cerita yaitu $\mathrm{H}$. Sukarding sehingga diperoleh informasiinformasi mengenai tokoh dan tempat yang akan divisualisasikan.

Tahap pertama yang dilakukan adalah membuat konsep desain Konsep dalam cerita rakyat Assalenna Cakkelleq Riala Lambang ri Soppeng yaitu tentang petualangan orang zaman dahulu mencari pemimpin untuk Kabupaten Soppeng yang sedang dilanda kekacauan. Tahap kedua yaitu membuat sketsa storyboard dan storyline sebagai acuan yang akan diterapkan pada tahap sketsa iluatrasi komik. Storyboard yang dibuat masih dalam bentuk sketsa kasar dalam artian belum dilengkapi dengan bentuk karakter yang jelas.

Selanjutnya, tahap pembuatan karakter cerita rakyat. Visualisasi karakter dibuat berdasarkan foto-foto zaman dahulu yang ada di internet dengan membuat sketsa-sketsa ciri khas dari foto tersebut. Maka dari hal tersebut diperolehlah karakter- karakter tokoh yang sesuai dengan ciri khas bugis.

Setelah melalui tahap pembuatan karakter, maka dibuatlah digitalisasi cerita rakyat Assalenna Cakkelleq Riala Lambang ri Soppeng. Implementasi digital ini iproses dengan melaui 3 tahap yaitu lineart, pewarnaan, dan pemberian teks. Pertama-tama, sampul komik dibuat dengan ukuran $18 \times 24$ $\mathrm{cm}$, final desain yang dihasilkan yaitu dengan ilustrasi burung Kakatua untuk menonjolkan peran burung Kakatua dalam cerita tersebut. Warna yang digunakan pada sampul komik tidak terlalu mencolok karena digunakan latar langit berwarna biru untuk membuat audiens fokus ke burung Kakatua. Selanjutnya, isi cerita yang dirancang dengan menggunakan warna yang menonjol pada bagian tertentu yaitu pada tokoh-tokoh atau tempat-tempat dalam cerita tersebut.

Hasil perancangan ini diharapkan dapat menjadi referensi bagi anak- anak dan dapat membuat anak-anak tertarik mempelajari bahasa daerah serta anak juga dapat memahami cerita tentang Sejarah Kabupaten Soppeng itu sendiri, terutama Cerita Rakyat tentang 
Assalenna Cakkelleq riala Lambang ri Soppeng.

\section{Saran}

Sebagai manusia yang masih banyak kekurangan, dalam perancangan komik cerita rakyat Assalenna Cakkelleq riala Lambang ri Soppeng ini masih jauh dari kata sempurna dan masih terdapat banyak kekurangan. Oleh karena itu, perlu dikembangkan dan disempurnakan lebih lanjut. Adapun beberapa saran yang disampaikan oleh penulis antara lain:

1. Dalam menceritakan kembali kisah sejarah melalui media baru perlu diperhatikan data yang didapatkan dan perlu ada verifikasi ulang dari budayawan atau sejarahwan untuk dipertanggung jawabkan.

2. Untuk mengembangkan cerita rakyat Assalenna Cakkelleq riala Lambang ri Soppeng diharapkan untuk memperhatikan atau menyesuaikan dengan target audiens yang akan dituju.

\section{DAFTAR PUSTAKA}

Anafiah, S. (2015). Pemanfaatan Cerita Rakyat Sebagai Bacaan Bagi Anak. Jurnal Pendidikan ke-SD-an, 128-129.

Erine, L. (2017, April 26). Kompasiana.com. A subsidiary of KG Media. Dipetik Mei 13, 2019, dari Kompasiana.com: https://www.kompasiana.com/luciaeri ne/590008b6f37a61518802008/perbe daan- pola-fikir-masyarakat-kota-dandesa

Maharsi, I. (2016). Ilustrasi. 2016: Badan Penerbit ISI Yogyakarta

Moh. Eka Lesmana, R. A. (2015). Perancangan Komunikasi Visual Komik Berbasis Cerita Rakyat Timun Mas. EProceeding of Art \& Design, 115.

Nadlir. (2014). Urgensi Pembelajaran Berbasis Kearifan Lokal. Jurnal Pendidikan Agama Islam, 300.
Said, A. A. (2006). Dasar Desain Dwimatra. Makassar: Badan Penerbit UNM Makassar.

Sambada, H. B. (2016). Pengembangan Komik Digital Berbasis Nilai Karakter Sebagai Media Pembelajaran Akuntansi Pada Kompetensi Dasar Akuntansi Persediaan Di Kelas XI Akuntansi. 55.

Sukarding. (2018). Muatan Lokal Bahasa Daerah Bugis untuk SMP/MTs Kelas VIII Ada Pappaseng. Soppeng. 